patients had been successfully relieved of pain or depressive symptoms as a result of such surgery to support the contention that it was a potentially beneficial therapy.

Others still claim, however, that although psychosurgery may be effective in alleviating symptoms such as pain and depression, this is frequently at the expense of sacrificing other aspects of the individual's identity, such as emotional responsiveness and creativity. It is also claimed that the psychosurgeons approach reduces social behaviour to a purely biological phenomenon, thus denying a range of environmental factors which alternative forms of treatment, such as psychotherapy, can take into account.

"There is no scientific foundation for attempting to control a specific aspect of social behaviour by destroying a portion of the human brain", says Dr Stephan Chorover, Professor of Psychology and Brain Science, at the Massachusetts Institute of Technology, who has given evidence during the court hearings. "The main thrust of this approach to social problem solving is that it tries to localise the problem in 'defective individuals' and therefore embodies a decision not to search for problems in the larger social system".

Whichever way the court decision goes, it is unlikely to resolve the wider philosophical issues surrounding the use of psychosurgery, since the matters on which the jury has been asked to judge relate essentially to the adequacy of the medical procedures followed prior to and during the treatment.

At the same time, however, it could provide a precedent for further legal actions. Already a second case is being brought on behalf of a girl who, at the age of 19 but without her consent, and after a series of electric shock treatment but minimal psychotherapy, had a cingulotomy-a lesion of the cingulum-performed by another Boston surgeon. This case is scheduled to be heard shortly.

\section{Scientist may sue over}

THE Supreme Court has agreed to rule on whether Senator William Proxmire committed libel when he made a "Golden Fleece" award to a scientist engaged in a study for NASA of teeth-clenching by monkeys.

Senator Proxmire, who is chairman of the Senate Appropriations Subcommittee responsible for the budgets of both NASA and the National Science Foundation, has frequently made such awards to esoteric- or naive-sounding research projects, which he claims to be an unncessary drain on the public purse. One recipient of the award was a research scientist, $\mathrm{Dr}$ Ronald $\mathrm{R}$.

\title{
More dangerous smallpox labs?
}

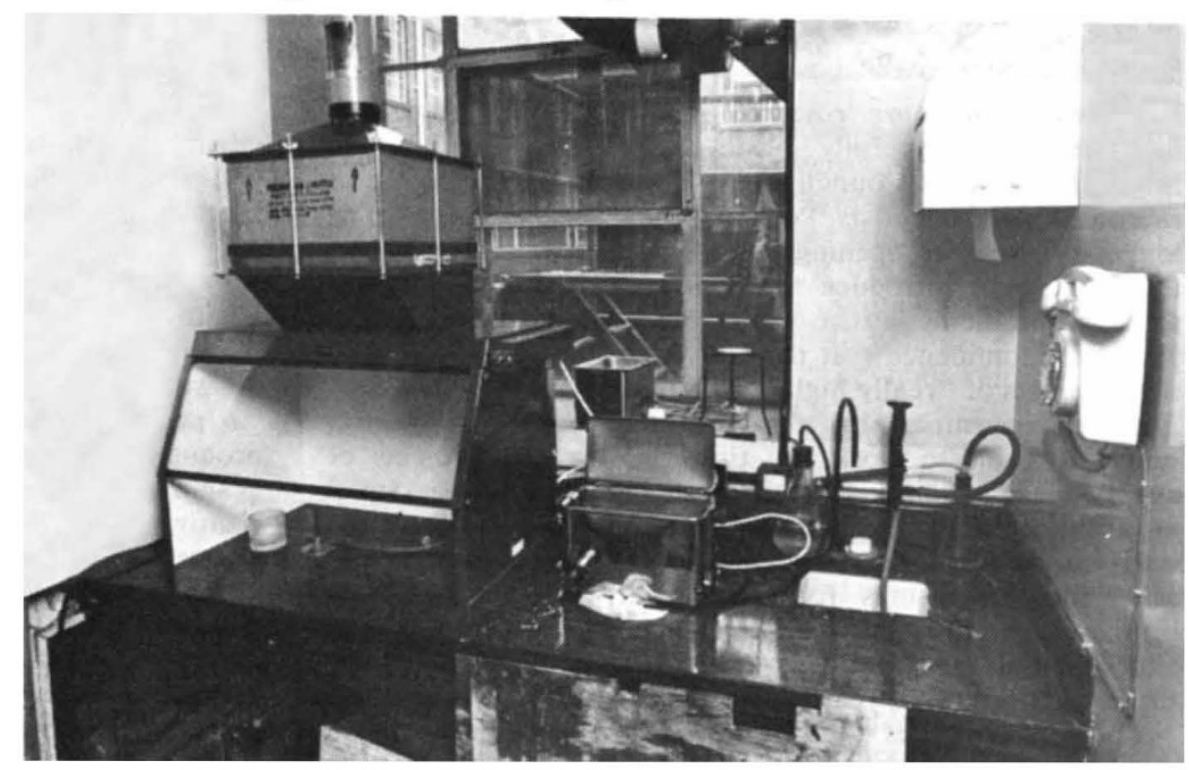

Above: the smallpox laboratory at Birmingham University from which the virus escaped last August. A possible route of infection-through a cable duct-appears bottom left.

As FAR as the World Health Organisation (WHO) is aware there are now nine laboratories in the world holding live smallpox virus; but only three of them-those in London, Hamburg and Atlanta-are known to match up to WHO smallpox laboratory safety recommendations. The laboratories at St Mary's Hospital, London and the Centre for Disease Control, Atlanta are to become WHO collaborating centres for poxvirus research; so is the Research Institute of Viral Preparations, Moscow, which is currently making modifications to come up to the WHO standard.

The Institut fur Schiffs und Tropenkrankheiten in Hamburg, the Rijks Institut voor de Volksgezondheid, Bilthoven, the Netherlands, the US Army Medical Research Institute for Infectious Diseases and the American Type Culture Collection are all considering either destroying or transferring their viruses to one of the WHO collaborating centres. The latter three labora- tories have not been visited by WHO. The other two laboratories currently holding smallpox virus are in Peking (which WHO has no plans to visit) and South Africa, which does not come up to standard, is storing the virus, but doing no research. Only the Centre for Disease Control in Atlanta is doing smallpox research at the moment.

The risks of laboratory infection should be seen in proportion, however. The WHO smallpox eradication unit has reduced the death rate from the disease from one million per year 10 years ago to probably zero this year. And smallpox is not an easily transmitted disease : it is not as infectious as flu or measles, for example.

- Correction: six white coats per laboratory worker were recommended by the Howie report on a code of practice for the prevention of infection in clinical laboratories, not the Godber report on the handling of dangerous pathogens, as indicated in last week's leader.

\section{"Golden Fleece" award}

Hutchinson, of Kalamazoo, Michigan, who, according to $\mathrm{Mr}$ Proxmire, has received more than $\$ 500,000$ in federal funding for research that includes measuring the latent aggression of laboratory monkeys under various conditions by recording electrical impulses in the jaw muscles.

Although NASA has said that the work was of particular importance in its efforts to identify aggressive personality traits in selecting crews for long space flights, Mr Proxmire called the research an outrageous example of "wasteful, extravagant, stupid spending".
A lower court rejected a libel action for $\$ 8$ million brought by the research worker partly on the grounds that he had become a "public figure" by soliciting government grants and publishing occasional articles in professional journals. Senator Proxmire also claimed legislative privilege. The Supreme Court has now agreed to hear an appeal from Dr Hutchinson, who claims that, as a result of the award, he has suffered injury to his reputation. illness, mental anguish and prospective loss of economic advantage. 